\title{
2009 evidence-based clinical practice guidelines for diagnosing first episodes of lower extremities deep vein thrombosis in ambulatory outpatients*
}

\author{
Roman Jaeschke ${ }^{1,2}$, Piotr Gajewski ${ }^{2,3}$, Shannon M. Bates ${ }^{1,4}$, James Douketis ${ }^{1}$, \\ Bogdan Solnica ${ }^{5}$, Mark Crowther', Wiktoria Leśniak ${ }^{2,3}$, Jan L. Brożek ${ }^{2,3,6}$, \\ Holger J. Schünemann ${ }^{1,6}$, Krystyna Zawilska7, Witold Tomkowski ${ }^{8}$, Anetta Undas ${ }^{8}$, \\ Jan Sznajd ${ }^{2,3}$, Rafał Niżankowski³, Małgorzata M. Bała ${ }^{2,3}$, Gordon Guyatt ${ }^{1,6}$

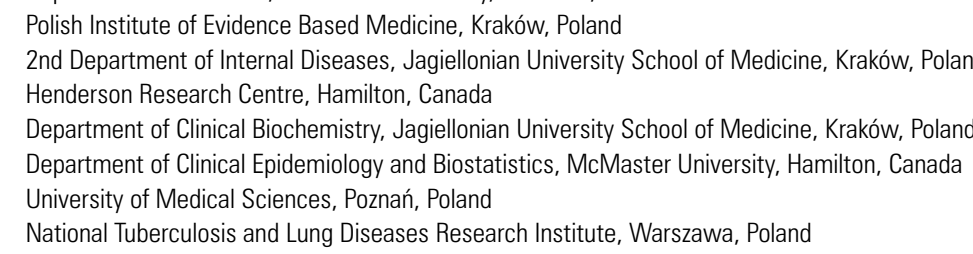

\section{KEY WORDS}

GRADE, diagnosis, practice guidelines, thrombosis

\section{ABSTRACT}

INTRODUCTION The GRADE working group has recently suggested a rigorous framework for clinical practice guidelines (CPG) addressing diagnostic tests and test strategies based on the impact of alternative approaches on patient-important outcomes. The framework mandates explicit evidence summaries, ratings of the quality of evidence, and specifying recommendations as strong or weak. OBJECTIVES To test the feasibility and performance of the GRADE approach, we applied this framework to well-researched issues in the diagnoses of deep venous thrombosis (DVT).

METHODS After identifying pertinent clinical questions, we searched existing CPG and systematic reviews for relevant studies. We summarized the data in form of evidence tables and developed recommendations including, when needed, a formal consensus process.

RESULTS AND CONCLUSIONS We provide three groups of recommendations for clinicians practicing in settings with access to different types of D-dimer tests - highly sensitive, moderately sensitive, and no availability of $\mathrm{D}$-dimer. We consider the use of clinical prediction rules in guiding the diagnostic process, the potential for negative D-dimer or venous ultrasound (US) to rule out disease, and the role of follow-up testing (US following positive D-dimer result, D-dimer following negative US, and serial US) depending on the probability of DVT at the start of diagnostic process. We recommend the following: that clinicians without access to a highly or moderately sensitive D-dimer test rely on US to guide DVT diagnosis; that those with access use the highly sensitive D-dimer to determine, in patients with low or moderate probability of DVT (by the Wells rule) whether US is needed; that in patients with low pre-test probability (pre-TP) and a negative D-dimer (either highly or moderately sensitive) they follow patients without further testing; that in patients with high pre-test probability they perform a compression ultrasound without D-dimer testing. 
INTRODUCTION The ultimate goal of choosing one management strategy over another is to improve outcomes that patients find important. For a variety of reasons, diagnostic tests may be accurate but fail to improve such outcomes. ${ }^{1}$ Thus, clinical practice guideline panels should base judgments of the quality of evidence and recommendations for diagnostic tests not solely on accuracy, but must consider the likelihood of patient benefit.

Providing a structure for guideline panels to consider quality of evidence and strength of recommendations for diagnostic tests based on impact on patient-important outcomes is a challenging task. Recently, the GRADE working group has provided such a structure. ${ }^{2,3}$ In this paper, we test the feasibility and performance of the GRADE approach by applying this framework to well-researched issues in the diagnoses of deep venous thrombosis (DVT).

Prompt diagnosis of DVT is important to prevent pulmonary embolism (PE) which can be rapidly fatal. Diagnosing DVT when it is not present places patients at increased risk for bleeding as a result of anticoagulation. Thus, achieving optimal patient outcomes requires an accurate, prompt diagnosis of DVT.

Clinicians use three categories of information to determine the probability of DVT:

1 clinical prediction rules based on the patient's history and clinical presentation

2 results of D-dimer test

3 results of radiological tests, most commonly compression venous ultrasound (CUS), much less frequently venography, and even less frequently magnetic resonance imaging.

This paper provides evidence-based clinical practice guidelines (CPG) focusing on the diagnosis of first episode of DVT in the ambulatory setting (outpatient or emergency room, i.e., not among hospitalized patients) using the GRADE framework. We do not address issues pertaining to the specific diagnosis of PE, recurrent DVT, upper extremity DVT, and pregnancy-associated DVT.

METHODS Development of recommendations A group of individuals with an interest in venous thromboemblism (VTE) and practice guidelines development methodology identified questions pertaining to the diagnosis of DVT (for eligibility criteria see Table 1, Appendix A). We searched for evidence addressing these questions by examining studies cited in related CPG and meta-analyses identified by reviewing the National Guideline Clearinghouse ${ }^{4}$, the National Library of Medicine (PubMed), the Cochrane Library, CINAHL and EMBASE (using search terms: ultrasonography, D-dimer, DVT, specificity, systematic). We developed recommendations on the basis of this evidence.

Assessing quality of evidence and strength of recommendations Following the approach articulated by GRADE for formulation of recommendations related to diagnosis, we first considered the quality of evidence (representing our confidence that an estimate of the effect of a testing strategy on patient outcome is sufficient to support a partic ular recommendation). Eligible studies included both those addressing diagnostic accuracy (cross-sectional accuracy studies) and studies examining the consequences of particular diagnostic strategies (prospective management studies). We considered both accuracy and management studies as providing high quality of evidence, unless downgraded by the following factors - limitation of design and execution (e.g., unrepresentative patients, lack of independent assessment of test and criterion standard), inconsistency (differences between the results), indirectness with respect to the population studied, the tests performed or the outcome measured, lack of sufficient precision and risk of publication bias. We used the following categories for the quality of evidence: high (A), moderate (B), low $(C)$, and very low $(D)$. We graded the strength of recommendations as "strong" (1) or "weak" (2) depending on the degree of our confidence that following recommended course of action will lead to optimal patient outcomes. When recommendations are strong we use the wording "we recommend"; when recommendations are weak, we use the wording "we suggest".

RESULTS Our search yielded a number of relevant practice guidelines ${ }^{5-10}$ and meta-analyses ${ }^{11-15}$. Tables 2-5 (Appendix A) summarize the evidence from those sources. Below we present the recommendations our panel developed on the basis of the evidence.

§1. Recommendations Clarifications Understanding these recommendations requires knowledge of the following:

1 Our recommendations rely on pre-test probability (pre-TP) estimates generated by validated clinical prediction rules. ${ }^{11}$

2 When, following testing, the probability of DVT is $<2 \%$, we recommend (or suggest, depending on the precision of estimates of probability) clinical follow-up alone; if the probability of DVT is $\geq 2 \%$, we recommend or suggest further testing. The threshold of $2 \%$ represents the consensus of the authors.

3 Although we did not formally model the impact of alternative strategies on the key outcomes of death and disability from venous thrombosis and bleeding, our threshold of $2 \%$ for the probability of DVT, and our requirement for a positive proximal leg US for diagnosis, minimizes the likelihood of adverse outcomes of either thrombosis or bleeding. On the other hand, this low threshold places a low value on avoiding additional diagnostic testing. Those who place a higher value on avoiding diagnostic testing, and a lower value on avoiding thrombosis or bleeding, would choose a higher threshold. 


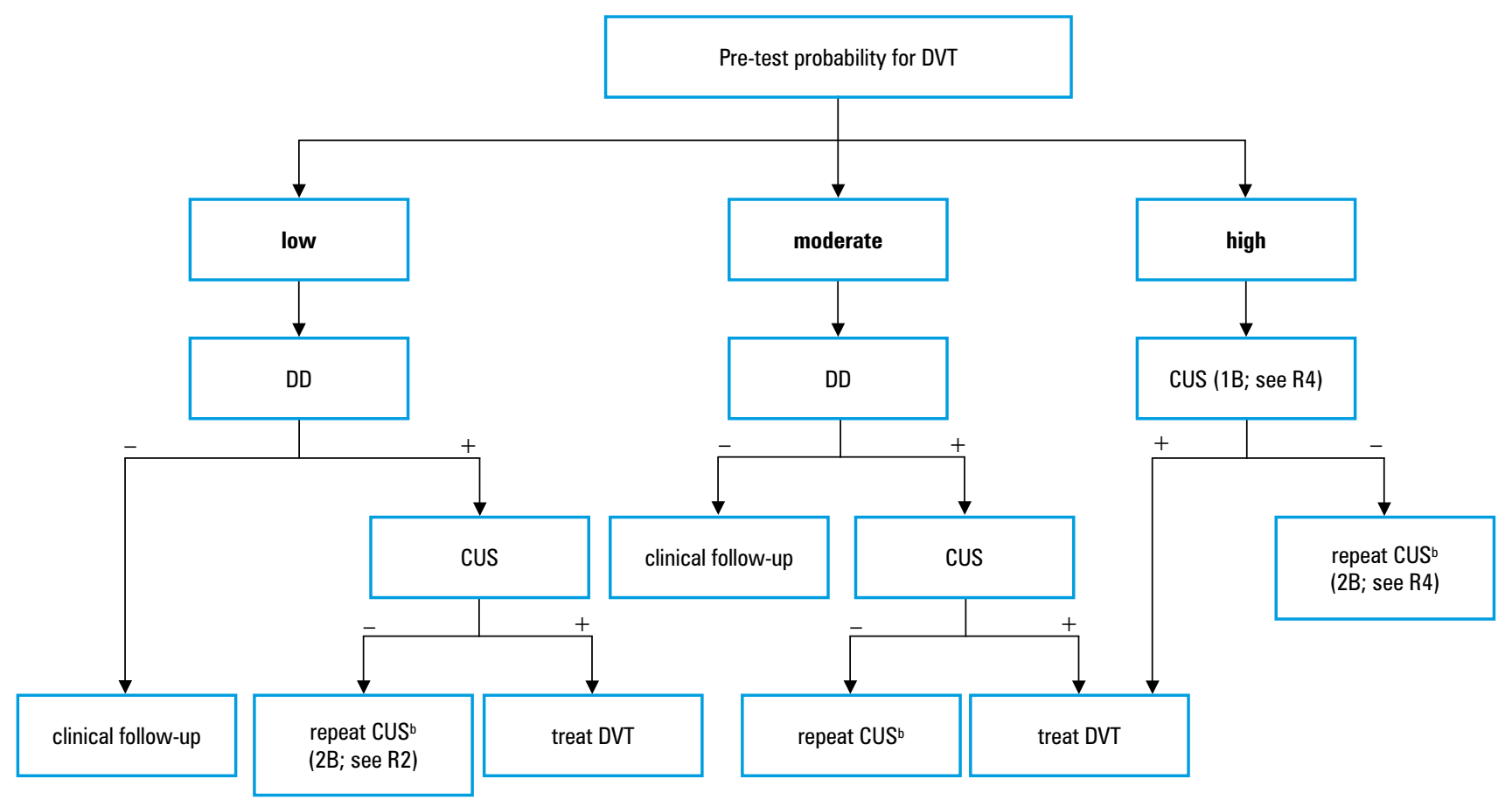

FIGURE 1 Algorithm of DVT diagnosis when highly sensitive D-dimer test is used (sensitivity approx. 95\%) a

a all recommendations grade $1 \mathrm{~A}$ unless otherwise stated b in 5-7 days Abbreviations: CUS - commpression ultrasound, DD - D-dimer test, DVT - deep vein thrombosis, pre-TP - pre-test probability, $\mathrm{R}$ - recommendation
4 Because D-dimer tests vary in accuracy, clinicians using these guidelines need to be familiar with the product they are using.

5 Our recommendations assume that CUS examines the proximal veins of lower extremity (common femoral, femoral and popliteal, often including the most proximal portions of the peroneal and tibial veins).

6 Our recommendations to repeat CUS refer to repeat testing in 5-7 days.

7 Evidence suggests that the accuracy of CUS, duplex US and triplex US are essentially equivalent ${ }^{15}$ and CUS is less expensive; therefore, all recommendations refer to the use of CUS.

8 By clinical follow-up we mean subsequent monitoring according to clinician judgment with no obligatory testing.

9 Review of Tables 2-5 will clarify the rationale for our recommendations.

We subsequently expand on some of the above statements.

Recommendations R1-R4 below assume use of highly sensitive D-dimer test (sensitivity approximateIy $\mathbf{9 5 \%}$, FIGURE 1)

$\mathrm{R} 1$. In patients with a low or moderate pre-TP, we recommend $\mathrm{D}$-dimer as the initial test with clinical follow-up if negative, and CUS of the proximal veins if positive, over initial testing with CUS (1A) (Tables 2-3, §2.3, §2.9).

R2. In patients with a low pre-TP, positive D-dimer and negative CUS, we suggest repeat CUS over clinical follow-up without repeat CUS or CUS of the distal veins (2B) (Table 5, §2.8).

R3. In patients with a moderate pre-TP, positive D-dimer, and a negative CUS we recommend repeat CUS over clinical follow-up (1A) (Table 5, $\S 2.8)$.
R4. In patients with a high pre-TP for DVT we recommend CUS as an initial test over other initial strategies (empiric treatment, venography, D-dimer) (1B). We further recommend treatment if the initial CUS is positive (1A) and suggest repeat CUS over performing $D$-dimer during initial visit if the first CUS is negative (2B) (Tables 2-4, $\S 2.3, \S 2.6, \S 2.7)$.

Recommendations R5-R8 assume use of moderately sensitive D-dimer test (sensitivity approximately $\mathbf{8 5} \%$, FIGURE 2)

R5. In patients with a low pre-TP, we recommend D-dimer with clinical follow-up if negative, and CUS if positive, over CUS in all (1A) (Tables 2-3, §2.3, §2.9).

R6. In patients with a low pre-TP, positive D-dimer, and negative CUS we suggest repeat CUS over clinical follow-up alone (2B) (Table 5, §2.8).

R7. In patients with a moderate pre-TP for DVT, we recommend CUS over other initial strategies (empiric treatment, venography, D-dimer) (1A). We recommend treatment if CUS is positive (1A). In patients with negative CUS, we recommend Ddimer during initial visit over repeat CUS, with repeat CUS if D-dimer is positive and clinical follow-up if negative (1A) (Tables 2-4, §2.3, §2.6, $\S 2.7)$. Underlying values and preferences: this strong, rather than weak, recommendation assumes cost and convenience advantages of D-dimer over CUS. If those are not important issues, repeat CUS offers an appropriate alternative.

R8. In patients with a high pre-TP for DVT, we recommend CUS over other initial strategies (empiric treatment, venography, D-dimer) (1A) and we recommend treatment if CUS is positive (1A). In those patients with negative CUS we suggest repeat CUS over performing D-dimer during initial visit (2B) (Tables 2-4, §2.3, §2.6, §2.7). 


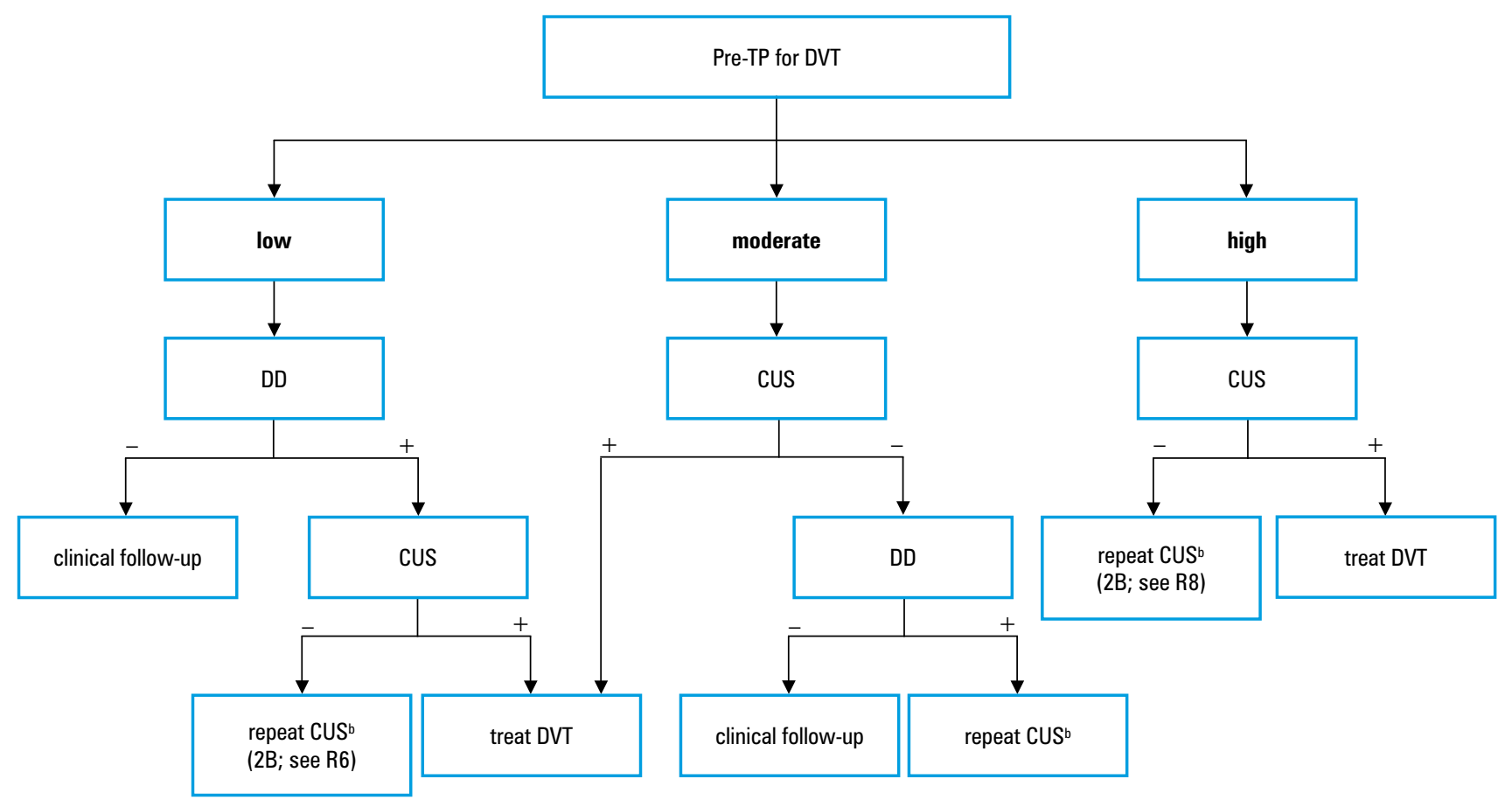

FIGURE 2 Algorithm of DVT diagnosis when moderately sensitive D-dimer test is used (sensitivity approx. 85\%) ${ }^{\text {a }}$ a all recommendations grade $1 \mathrm{~A}$ unless otherwise stated b in 5-7 days Abbreviations: See FIGURE 1
Recommendations R9-R13 below assume D-dimer tests described above are not available (FIGURE 3)

R9. In patients with suspected DVT, we recommend CUS of the proximal veins over other strategies as an initial test (1A) (Table 3, §2.6).

R10. In patients with a low pre-TP for DVT and negative CUS, we recommend clinical follow-up over further testing (1A) (Table 3, §2.6).

R11. In patients with low pre-TP and positive CUS, we suggest treatment with no further testing over venography to confirm DVT (2A) (Table 3, §2.6). Underlying values and preferences: our suggestion of treatment over venography assumes a high value on avoiding the pain and inconvenience and complications of venography, and a lower value on avoiding the bleeding risk and inconvenience associated with anticoagulation.

$\mathrm{R} 12$. In patients with a moderate-to-high pre-TP for DVT and positive CUS, we recommend treatment over further testing (1A) (Table 3, §2.6).

R13. In patients with a moderate-to-high pre-TP for DVT and negative CUS, we recommend repeat CUS over clinical follow-up (1B) (Table 3, §2.6, §2.7).

\section{Other recommendations not related to $\mathrm{D}$-dimer availability}

R14. In patients with suspected DVT who have an equivocal or inadequate CUS we recommend prompt repeat CUS or venography over long-term treatment or clinical follow-up (1A) (Table 3, §2.7) Comment: the choice of the tests may depend on the technical and clinical skills available and individual patient's clinical circumstances.

R15. In patients with moderate or high pre-TP, when diagnostic tests are delayed we recommend treatment until tests are available over no treatment (1A); in such patients with a low pre-TP, we suggest treatment over no treatment (2B) (§2.1)

\section{§2. Further rationale for recommendations}

2.1. Our recommendations rely on pre-TP estimates generated by clinical prediction rules All our recommendations require an estimate of pre-TP. All studies that provided the evidence on which we rely used clinical prediction rules (e.g., those developed by Wells et al., Appendix B) to estimate pre-TP of VTE. The rules are based on combinations of clinical assessment of risk factors and physical findings - individual clinical features are poorly predictive. The prevalence of DVT in categories of pre-TP varies considerably across studies: in the original study by Wells et al. those probabilities were 3,17 , and $75 \%$ for low, moderate, and high pre-TP, respectively. ${ }^{16}$ In the review by Tamariz et al. the observed range of probabilities was $0-13 \%$ for low pre-TP, $0-38 \%$ for moderate pre-TP, and $17-85 \%$ for high pre-TP. ${ }^{11}$ Whether the results in Tables 2-5 also apply to other approaches to generating pre-TP (e.g., clinical judgment) is uncertain. Some clinical situations may increase the probability of DVT regardless of prediction rules score (e.g., presence of vena cava filter or concurrent symptoms consistent with pulmonary embolism).

\subsection{Our recommendations assume that a post-TP of} $<2 \%$ is required in order to recommend or suggest clinical follow-up rather than further tests Diagnostic strategies for DVT often seek to reduce the probability of DVT to a level that justifies clinical follow-up rather than repeat testing. Since we cannot reduce the probability to $\leq 1 \%$ (even normal results of venography leave a probability of VTE of up to approximately $1-2 \%)^{17}$, we use a threshold of $2 \%$ for further investigation vs. clinical follow-up alone. That is, if after applying a diagnostic strategy the probability of DVT is greater than $2 \%$, we recommend or suggest additional 
FIGURE 3 Algorithm of DVT diagnosis when moderately or highly sensitive D-dimer test is not available

a all recommendations grade $1 \mathrm{~A}$ unless otherwise stated

b $2 \mathrm{~A}$ if pre-TP is low (see R11), 1A if pre-TP is moderate-high c in 5-7 days Abbreviations: See FIGURE 1

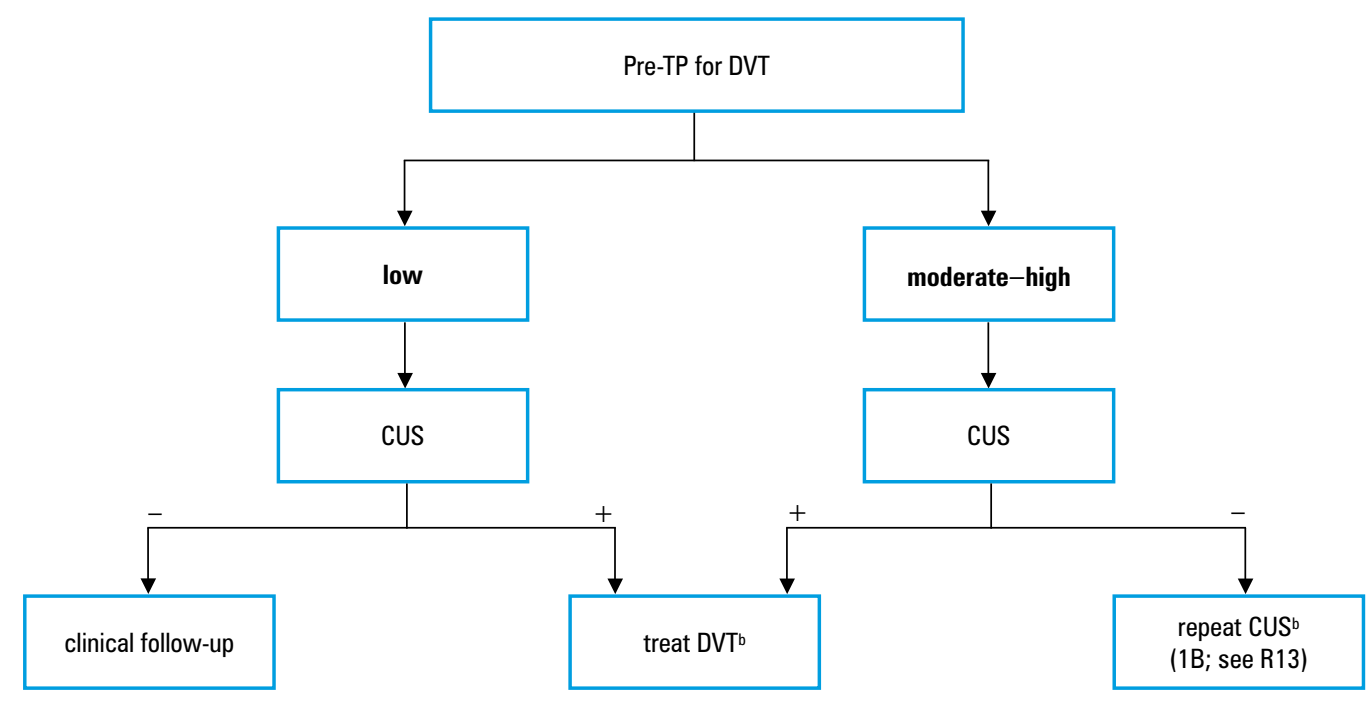

testing. If the probability is less than $2 \%$ we recommend or suggest clinical follow-up with additional testing if new or progressive symptoms occur. When the confidence interval around the point estimate of the probability of DVT crossed the $2 \%$ threshold, we rated quality down for imprecision. Tables $2-5$ provide the necessary information to choose an appropriate course of action for different thresholds. The threshold is likely to differ across patients, and this is reflected in the strength of our recommendations.

2.3. Different D-dimer tests have different characteristics (and thus require differing recommendations for use) There exist a variety of D-dimer assays with different test properties. Authors of a systematic review of rapid D-dimer assays (their rapidity making them suitable for outpatient use) report summary estimates of highly sensitive D-dimer assay sensitivity as $97.7 \%$ (95\% CI 96.1-99.0\%) and specificity of $45.7 \%$ (95\% CI 28-66.6\%) with a likelihood ratio (LR) for a negative test result of $0.05 .{ }^{12}$ Another systematic review found similar estimates of sensitivity ( 95\%) among assays collectively labeled as highly sensitive D-dimer tests (ELISA, rapid ELISA, immunoturbidimetry). ${ }^{13}$

Authors of the systematic review summarizing results of management studies of rapid D-dimer based diagnostic strategies concluded that the negative result of a highly sensitive $\mathrm{D}$-dimer test indicated less than $0.5 \%$ 3-month probability of VTE among outpatients with low-to-moderate pre-TP (but over $6 \%$ probability among patients with high pre-TP; Table 2; R1, R4). ${ }^{12}$

In contrast, the summary estimate of sensitivity of the moderately sensitive SimpliRed D-dimer test (also referred to as whole blood, qualitative hemagglutination assay) is $87.5 \%$ (95\% CI $82.4-$ $91.7 \%)$, and the summary estimate of specificity is $76.9 \%$ (95\% CI $65.4-86.2 \%$ ) with the LR for a negative test result $0.16{ }^{12}$ In management studies the negative results of the most studied rapid D-dimer assay of moderate sensitivity among patients with a low pre-TP were associated with a 3-month probability of VTE of $0.5 \%$ (95\% CI 0.07-1.1\%; Table 2; R5); moderate sensitivity tests can therefore effectively rule out DVT in such patients. On the other hand, the incidence of DVT was $3.5 \%$ and $21.4 \%$ in those with a moderate or high pre-TP and a negative test, respectively, thus precluding initial use of the moderately sensitive D-dimer to exclude DVT in this population (R7, R8). ${ }^{12}$

Aside from the highly and moderately sensitive D-dimer assays about which we make recommendations, there are also low sensitivity D-dimer tests available. These tests are, however, used in investigations of disseminated intravascular coagulation. Again, we emphasize that clinicians should be aware of which test they are ordering.

Another reservation about D-dimer relates to the timing of presentation and use of anticoagulants. The sensitivity of D-dimer test is reduced if the duration of symptoms or signs exceeds 2 or 3 days prior to the test or with the use of heparin before testing. ${ }^{10}$

Lastly, specificity of all available D-dimer assays is too low to allow use of those tests to confirm presence of VTE, hence further diagnostic tests are required (R1-R8).

Appendix $C$ presents the performance characteristics of different D-dimer tests in more detail.

2.4. Our recommendations assume that CUS examines the proximal veins of lower extremity (popliteal, superficial femoral, and common femoral) Two considerations support this approach. First, the accuracy of CUS to detect DVT below the popliteal vein is inconsistent and appears to be highly operator dependent. Second, the significance of clots in the calf is uncertain (whether, for instance, they cause PE and how often they do so). ${ }^{18}$

\subsection{Our recommendations to repeat CUS includes} a time frame of 5-7 days When we refer to repeat CUS, we assume a time frame of 5-7 days for 
repeat testing. ${ }^{15}$ When we refer to "clinical followup", we imply no additional testing towards DVT unless new or progressive symptoms occur.

2.6. Our recommendations assume use of CUS as a preferred radiological test Contrast venography remains the definitive test to rule out the diagnosis of DVT. It has, however, numerous drawbacks including resource use, technical challenges, discomfort to the patient, limited availability, risk of adverse effects from IV contrast, and secondary thrombosis. For these reasons, venography is generally reserved for research studies and for highly selected patients who pose a diagnostic dilemma (R14).

The sensitivity of CUS is approximately $95 \%$ for the diagnosis of symptomatic proximal lower extremity DVT (Table 3; R1-15).8,9,15 The sensitivities of different modes of US differ only slightly $(93-96 \%)^{15}$ and such differences are unlikely to be of clinical significance: sensitivities for detection of proximal DVT from 93.8 for CUS (95\% CI 92-95.3\%) to $96.5 \%$ for duplex US (95\% CI 95.1-97.6\%). Specificity of CUS is $97.8 \%$ (95\% CI 97-98.4\%), numerically slightly higher than for duplex (94\%; 95\% CI 92.8-95.1\%) or triplex US (94.3\%, 95\% CI 92.5-95.8\%).

According to a review of US performance ${ }^{15}$, limitations of US sensitivity do not translate into high rates of adverse outcomes. This is probably due to repeated testing in a population of higher pre-TP (or those with a positive D-dimer), high negative predictive value when a reasonably sensitive test is applied to a population with low disease prevalence, and finally, because DVT that is not detected by US may have a relatively benign natural history.

Considering all of the above, a single negative US does not rule out DVT with sufficient certainty in patients with moderate or high preTP of DVT, where the prevalence of DVT among such patients may be up to $4 \%$ (Table 3 ; R3, R4, R7, R8, R13). ${ }^{15,17}$

CUS is an operator-dependent procedure. All our recommendations assume that CUS in individual institutions retains the measurement properties demonstrated in the published studies. Anecdotal experience suggests this is not always the case. To the extent that CUS in some hospitals is less accurate, the evidentiary basis for our recommendations is indirect (and the quality of evidence should be downgraded for indirectness). Despite this uncertainty, we have chosen not to downgrade for indirectness.

\subsection{Management strategies following negative CUS result in patients with moderate or high pre-} TP Following a first negative CUS (conducted as the initial test) in patients with a moderate or high pre-TP for DVT, an acceptable diagnostic strategy may include subsequent moderately sensitive or highly sensitive D-dimer performed at the time of initial presentation. Among patients with moderate to high pre-TP and negative initial
CUS the 3-month prevalence of DVT is $2-4 \%{ }^{17}$ In such patients, the addition of negative D-dimer lowers the probability to $<1 \%$ (details below). Such a study, however, was not performed among only high pre-TP patients.

In one cohort study (overall prevalence of DVT 22\%), 828 patients with a negative initial CUS followed by a negative D-dimer test (moderately sensitive) had a DVT prevalence of $0.7 \%$ (95 \% CI $0.3-1.6 \%) .{ }^{19}$ In another cohort study involving 531 patients with a moderate-to-high pre-TP (65\% of whom had positive initial CUS), 148 patients with a normal CUS and normal D-dimer test (moderately sensitive) had a DVT prevalence of $0 \%$ (95\% CI $0-3 \%) .{ }^{20}$ In a third study involving 495 patients (overall prevalence of DVT 27\%), none of 81 patients with moderate-to-high pre-TP, negative D-dimer and negative CUS had VTE during a 3-month follow-up. ${ }^{21}$ Similar results were observed in the last of the four cohort studies in which the overall incidence of DVT was $\sim 28 \%$ and DVT occurred in 3 out of 598 people with negative CUS followed by a negative D-dimer. ${ }^{22}$

This strategy of using a moderately sensitive D-dimer (SimpliRed) was also tested and shown equivalent to repeat venous US in a randomized study by Kearon ${ }^{23}$ (overall prevalence of DVT was, however, below $10 \%$ ). In this study, $810 \mathrm{pa}-$ tients with a negative initial CUS were randomized either to repeat CUS, or to D-dimer testing followed, if $\mathrm{D}$-dimer positive, by venography. Among 309 patients with a negative initial CUS and negative D-dimer 3 (1\%, 95\% CI 0.2 $2.8 \%$ ) developed VTE during 6 months of followup. We have pooled available cohort studies using fixed effect model with resulting post-TP of $0.6 \%$ (95\% CI $0.3-1.1 \%$ ), with inclusion of RCT $0.7 \%$ (95\%CI 0.4-1.2\%) (Table 4; R4, R7, R8). To decide on our panel preference between CUS repeated 5-7 days later and D-dimer done immediately following first negative CUS we used the GRADE grid, a formal process to resolve differences of opinions. ${ }^{24}$ This approach led us to different recommendations depending on the pre$\mathrm{TP}$ : for patients with high pre-TP we suggest repeat CUS and for those with moderate pre-TP we recommend D-dimer (R4, $\mathrm{R} 7, \mathrm{R} 8)$.

If D-dimer is not available, repeat CUS is our preferred option in such patients (R13). If first CUS is inconclusive or inadequate, venography may be considered (R14). The choice of venography may depend on the technical and clinical skills available in a given health care setting, and clinical circumstances and preferences of individual patients.

\subsection{Management strategies following positive} D-dimer and negative CUS Patients with moderate-to-high pre-TP of DVT and positive D-dimer may have over $10 \%$ probability of VTE despite a negative first CUS. ${ }^{20}$ The relevant study did not separate moderate and high pre-TP patients. Those with moderate pre-TP, a positive D-dimer, and a negative initial CUS are likely to 
have a DVT prevalence lower than observed $18 \%$, but probably not below the threshold allowing no further testing (Table 5; R3).

The optimal management patients with low pre-TP of DVT, positive D-dimer, and subsequent negative CUS performed at initial presentation is not clear. The prevalence of DVT among patients with negative CUS followed by positive D-dimer may be as high as $6 \% .^{22}$ This estimate, however, was obtained in a population with an initial prevalence of DVT over 20\%. In a study including 896 patients with unequivocally low pre-TP, among 280 patients with negative initial CUS and positive D-dimer, 7 (2.5\%) had DVT detected on repeated screening CUS done because of positive Ddimer (there may have been other patients with symptomatic DVT in this subgroup - this is not clear from the report). ${ }^{19}$ In the previously quoted study by Wells et al, none of the 85 patients with positive D-dimer and negative CUS developed VTE during follow-up. ${ }^{21}$ In another study, calf vein DVT was detected by repeat CUS in 2 out of $113(1.8 \%)$ patients with positive D-dimer and originally negative CUS. ${ }^{25}$ Although this frequency and location of clots may be insufficient to warrant repeated CUS, our suggestion is to perform follow-up CUS (2B) (Table 5; R2, R6).

2.9. Our recommendations are intended exclusively for ambulatory out-patients presenting with symptoms associated with first episode of DVT Most studies were done in ambulatory care setting and involved patients with recent onset of symptoms who are not receiving anticoagulation therapy. ${ }^{26}$ The applicability of these studies' findings to other settings (including hospitalized patients) is limited, and our recommendations are not intended for such patients.

Patients with recent major trauma or surgery and those with cancer or pregnancy may have increased plasma D-dimer levels that will decrease the specificity and predictive value of the positive D-dimer test. Such results may also occur in common conditions that can present in a way similar as DVT - cellulitis, hematoma, musculoskeletal injury, inflammatory arthritis. The utility of $\mathrm{D}$-dimer may be also decreased in very elderly in whom the specificity of D-dimer is lower than in other populations. ${ }^{27}$ At the same time, as the sensitivity is not decreased, the usefulness of negative test results in ruling out disease is maintained.

DISCUSSION Our goal in writing this manuscript was to utilize an explicit and transparent methodology to provide a set of clinically relevant and comprehensive recommendations that clinicians can apply to patients with suspected lower limb DVT. In our preliminary work, we have found a number of CPGs in this area. Our CPG differs from those found in two ways. First, we have used the GRADE approach to judge both quality of evidence and strength of recommendations. Second, as our guidelines are written for clinicians working in different health care systems with different access to specific diagnostic tests (in this case, D-dimer assays) we provided three diagnostic algorithms (based on use of highly sensitive and moderately sensitive D-dimer, or no use of D-dimer).

Our recommendations and suggestions are, in general, similar to those of other available guidelines and review papers. ${ }^{8,10,28}$ Important differences from some, but not all, other guidelines include our recommendation to perform the highly sensitive $\mathrm{D}$-dimer assay as an initial test not only in patients with low but also moderate pre-TP of DVT, and to conduct only clinical follow-up in those with negative results. In some other cases we provide the rationale for and potential for alternative management strategies in areas where desirable and alternative consequences of alternative courses of action are unclear or closely balanced. This is true, for example, of our recommendations to perform either moderately or highly sensitive Ddimer test at the initial presentation in patients with moderate pre-TP following negative initial CUS, as opposed to repeating the CUS few days later. It is also true of our recommendation that in patients with high pre-TP clinicians repeat CUS 5-7 days later as opposed to performing D-dimer test at the original presentation.

The diagnostic reasoning in DVT is traditionally based on the ability of different diagnostic strategies to rule out the disease. None of these strategies is perfect. Even the reference standard - venography - may be associated with up to $2 \%$ of false negative rate (up to 20/1000 people with negative venogram may have proven DVT within 3 months clinical follow up time). Performance of CUS or D-dimer test alone is associated with more false negative results.

Deciding on the level of post-TP at which one may choose clinical follow-up alone over further testing is a subjective one, based not only on the available evidence, but also on the underlying values and preferences associated with the consequences of misdiagnosis (either missed DVT or unnecessary treatment) and resource use. Our guidelines are based on a threshold of $2 \%$. $\mathrm{Pa}$ tients' thresholds are likely to differ, and to the extent this is the case our recommendations may not apply. Patients with a lower threshold will almost always prefer subsequent testing to clinical follow-up; those with a higher threshold might on occasion prefer clinical follow-up rather than the additional testing we suggest.

The approach we have taken does have limitations. Rather than identifying and examining individual studies ourselves, we have collected and summarized evidence from meta-analyses produced by other authors. The evidence summarized in these meta-analyses is several years old, and the meta-analyses did not use the most recent methods for arriving at summary estimates. This represents a weakness of our guideline.

A second limitation is that we did not calculate the number of bleeding events that would occur with different diagnostic thresholds and 
formally include these in a trade off with thrombotic events, inconvenience and cost of antithrombotic therapy, and inconvenience and cost of testing. This is also true for our recommendation in favor of US rather than venography as the definitive diagnostic test. Future iterations of these guidelines would be strengthened by making such calculations and formal tradeoffs.

Our use of the GRADE system has mandated explicit evidence summaries, ratings of the quality of evidence, consideration of indirectness in rating quality of evidence, and specifying recommendations as strong or weak. Our explicit presentations of the evidence supporting our judgments in the tables and in the text, and our explicit statements regarding issues such as our diagnostic threshold, will facilitate constructive debate and help others to be transparent and explicit in making their own judgments.

Acknowledgments Each author certifies that the manuscript represents original and valid work and that neither this manuscript nor one with substantially similar content under his or her authorship has been published or is being considered for publication elsewhere. Each author agrees to allow the corresponding author to serve as the primary correspondent with the office, to review the edited typescript and proof, and to make decisions regarding release of information in the manuscript to the media, federal agencies, or both. Each author has given final approval of the submitted manuscript.

Each author certifies that he/she has participated sufficiently in the work to take public responsibility for the whole content (RJ, GG) or part of the content (all other authors), and each has made substantial contributions to the intellectual content of the paper as described below. RJ, GG and PG lead the conception and design of the study, but all authors contributed in this respect. PG, BS, PG, MB, WL, JB, JS, SB, MC, JD and WT contributed to acquisition of data, and all authors contributed to analysis and interpretation. RJ and GG drafted the manuscript and all authors provided repeated critical revision of the manuscript for important intellectual content. SB, JD, $\mathrm{MC}, \mathrm{KZ}, \mathrm{WT}, \mathrm{RN}$ and AU provided supervisory input from thromboembolism perspective, and GG, HS and JB from GRADE perspective. All authors participated in drafting and repeated revision of recommendations, resolving controversies and reaching consensus.

\section{REFERENCES}

1 Guyatt GH, Tugwell P, Feeny DH, et al. A framework for clinical evaluation of diagnostic technologies. Can Med Assoc J. 1986; 134: 587-594.

2 Guyatt GH, Oxman AD, Vist GE, et al. for the GRADE working group GRADE: an emerging consensus on rating quality of evidence and strength of recommendations. BMJ. 2008; 336: 924-926.

3 Schünemann $\mathrm{HJ}, 0 x$ man $A D$, Brozek $J$, et al. GRADEing the quality of evidence and strength of recommendations for diagnostic tests and strategies. BMJ. 2008; 336: 1106-1110.

4 http://www.guideline.gov/. Accessed February 16, 2008.
5 Keeling DM, Mackie IJ, Moody A, Watson HG. The Haemostasis and Thrombosis Task Force of the British Committee for Standards in Haematology. The diagnosis of deep vein thrombosis in symptomatic outpatients and the potential for clinical assessment and D-dimer assays to reduce the need for diagnostic imaging. $\mathrm{Br} \mathrm{J}$ Haematol. 2004; 124: 15-25.

6 Clinical policy: critical issues in the evaluation and management of adult patients presenting with suspected lower-extremity deep venous thrombosis. Ann Emerg Med. 2003; 42: 124-135.

7 Finnish Medical Society Duodecim. Deep vein thrombosis. In: EBM Guidelines. Evidence-Based Medicine [Internet]. Helsinki, Finland: Wiley Interscience. John Wiley \& Sons; 2006 Apr 27 [Various]. http://www. guideline.gov.

8 Qaseem A, Snow V, Barry P, et al. Current diagnosis of venous throm boembolism in primary care: a clinical practice guideline from the American Academy of Family Physicians and the American College of Physicians. Ann Fam Med. 2007; 5: 57-62.

9 Segal J, Eng J, Tamariz L, Bass E. Review of the evidence on diagnosis of deep venous thrombosis and pulmonary embolism. Ann Fam Med. 2007; 5: 63-73.

10 Institute for Clinical Systems Improvement. Health Care Guideline: VTE thromboembolism. 8th ed. June 2007. http://www.icsi.org/venous thromboembolism/venous_thromboembolism_4.html. Accessed Dec 10, 2007.

11 Tamariz LJ, Eng J, Segal JB, et al. Usefulness of clinical prediction rules for the diagnosis of venous thromboembolism: a systematic review. Am J Med. 2004; 117: 676-684.

12 Fancher TL, White RH, Kravitz RL. Combined use of rapid D-dime testing and estimation of clinical probability in the diagnosis of deep vein thrombosis: systematic review. BMJ. 2004; 329: 821.

13 Stein PD, Hull RD, Patel KC, et al. D-dimer for the exclusion of acute venous thrombosis and pulmonary embolism: a systematic review. Ann Intern Med. 2004; 140: 589-602.

14 Goodacre S, Sampson FC, Sutton AJ, et al. Variation in diagnostic performance of D-dimer for suspected deep vein thrombosis. $0 \mathrm{~J}$ Med. 2005; 98: 513-527.

15 Goodacre S, Sampson F, Thomas S, et al. Systematic review and meta-analysis of the diagnostic accuracy of ultrasonography for deep vein thrombosis. BMC Med Imaging. 2005; 5: 6

16 Wells PS, Anderson DR, Bormanis J, et al. Value of assessment of pretest probability of deep-vein thrombosis in clinical management. Lancet. 1997; 350: 1795-1798.

17 Michiels JJ, Gadisseur A, van der Planken M, et al. Different accuracies of rapid enzyme-linked immunosorbent, turbidimetric, and agglutination D-dimer assays for thrombosis exclusion: impact on diagnostic workups of outpatients with suspected deep vein thrombosis and pulmonary embolism. Semin Thromb Hemost. 2006; 32: 678-693.

18 Bernardi E, Camporese G, Büller H, et al. Serial 2-point ultrasonography plus D-dimer vs. whole-leg color-coded doppler ultrasonography for diagnosing suspected symptomatic deep vein thrombosis: a randomized controlled trial. JAMA. 2008; 300: 1653-1659.

19 Kraaijenhagen RA, Piovelli F, Bernardi E, et al. Simplification of the diagnostic management of suspected deep vein thrombosis. Arch Intern Med. 2002; 162: 907-911.

20 Tick LW, Ton E, van Voorthuizen T, et al. Practical diagnostic management of patients with clinically suspected deep vein thrombosis by clinical probability test, compression ultrasonography and D-dimer test. Am J Med. 2002; 113: 630-635.

21 Wells PS, Anderson DR, Rodger M, et al. Evaluation of D-dimer in the diagnosis of suspected deep vein thrombosis. N Engl J Med. 2003; 349: 1227-1235.

22 Bernardi E, Prandoni P, Lensing AW, et al. D-dimer testing as an adjunct to ultrasonography in patients with clinically suspected deep vein thrombosis: prospective cohort study. The Multicentre Italian D-dimer UItrasound Study Investigators Group. BMJ. 1998; 317: 1037-1040.

23 Kearon C, Ginsberg JS, Douketis J, et al. A randomized trial of diag nostic strategies after normal proximal vein ultrasonography for suspected deep venous thrombosis: D-dimer testing compared with repeated ultrasonography. Ann Intern Med. 2005; 142: 490-496.

24 Jaeschke $\mathrm{R}$, Guyatt $\mathrm{GH}$, Dellinger $\mathrm{P}$, et al. GRADE working group. Use of GRADE grid to reach decisions on clinical practice guidelines when consensus is elusive. BMJ. 2008; 337: 327-330.

25 Anderson DR, Kovacs MJ, Kovacs G, et al. Combined use of clinica assessment and D-dimer to improve the management of patients presenting to the emergency department with suspected deep vein thrombosis (the EDITED Study). J Thromb Haemost. 2003; 1: 645-651.

26 Schutgens RE, Esseboom EU, Haas FJ, et al. Usefulness of a semiquantitative D-dimer test for the exclusion of deep venous thrombosis in outpatients. Am J Med. 2002; 112: 617-621.

27 Aguilar C, del Villar V. Diagnostic performance of D-dimer is lower in elderly outpatients with suspected deep venous thrombosis. Br J Haematol. 2005; 130: 803-804.

28 Goodacre S, Stevenson M, Wailoo A, et al. How should we diagnose suspected deep vein thrombosis. 0JM. 2006; 99: 377-388. 


\title{
Rozpoznawanie zakrzepicy żył głębokich kończyn dolnych u pacjentów ambulatoryjnych - wytyczne 2009*
}

\author{
Roman Jaeschke ${ }^{1,2}$, Piotr Gajewski ${ }^{2,3}$, Shannon M. Bates ${ }^{1,4}$, James Douketis ${ }^{1}$, \\ Bogdan Solnica ${ }^{5}$, Mark Crowther ${ }^{1}$, Wiktoria Leśniak ${ }^{2,3}$, Jan L. Brożek ${ }^{2,3,6}$, \\ Holger J. Schünemann ${ }^{1,6}$, Krystyna Zawilska ${ }^{7}$, Witold Tomkowski ${ }^{8}$, Anetta Undas ${ }^{8}$, \\ Jan Sznajd ${ }^{2,3}$, Rafał Niżankowski³ ${ }^{3}$ Małgorzata Bała ${ }^{2,3}$, Gordon Guyatt1,6 \\ 1 Department of Medicine, McMaster University, Hamilton, ON, Kanada \\ 2 Polski Instytut Evidence Based Medicine, Kraków \\ II Katedra Chorób Wewnętrznych, Uniwersytet Jagielloński, Collegium Medicum, Kraków \\ Henderson Research Centre, Hamilton, ON, Kanada \\ Katedra Biochemii Klinicznej, Uniwersytet Jagielloński, Collegium Medicum, Kraków \\ Department of Clinical Epidemiology and Biostatistics, McMaster University, Hamilton, ON, Kanada \\ Uniwersytet Medyczny w Poznaniu, Poznań \\ 8 Instytut Gruźlicy i Chorób Płuc, Warszawa \\ 9 Instytut Kardiologii, Uniwersytet Jagielloński, Collegium Medicum, Kraków
}

\section{SŁOWA KLUCZOWE}

GRADE, rozpoznanie, wytyczne praktyki klinicznej, zakrzepica żył głębokich
Adres do korespondencji: Gordon Guyatt, MD, Department of Clinical Epidemiology and Biostatistics, McMaster University, 1200 Main Street West, Hamilton, Ontario, Canada, L8N 3Z5, phone: +1-905-525-91-40 fax: +1-905-524-38-41, e-mail: guyatt@mcmaster.ca Praca wptynęła: 15.08.2009. Przyjęta do druku: 18.08.2009 Nie zgłoszono sprzeczności interesów.

Pol Arch Med Wewn. 2009; 119 (9): 541-549 Copyright by Medycyna Praktyczna, Kraków 2009

* Pełna wersja artykułu jest dostępna na stronie internetowej czasopisma: http://tip.org.pl/pamw/

\section{STRESZCZENIE}

WSTĘP System GRADE zaproponował podejście do tworzenia wytycznych praktyki klinicznej (clinical practice guidelines - CPG) dotyczących stosowania badań i strategii diagnostycznych, oparte na ocenie wpływu alternatywnych metod postępowania na skutki zdrowotne ważne dla pacjentów. Podejście to wymaga przejrzystego podsumowania danych, oceny ich jakości i sformułowania zaleceń z określeniem ich siły.

CELE Aby ocenić możliwość i efektywność podejścia GRADE, użyliśmy tego schematu do stworzenia zaleceń dotyczących dobrze zbadanych kwestii rozpoznawania zakrzepicy żył głębokich (deep venous thrombosis - DVT).

METODY Po sformułowaniu pytań klinicznych przeszukaliśmy literaturę z uwzględnieniem istniejących CPG i przeglądów systematycznych. Wyniki podsumowaliśmy w postaci tabel (profili danych) formułując na ich podstawie zalecenia.

WYNIII I WNIOSKI Przedstawiamy trzy grupy zaleceń dla lekarzy praktykujących w warunkach z dostępem do różnego rodzaju oznaczeń dimeru $\mathrm{D}(\mathrm{DD})$, tj. testów o dużej lub umiarkowanej czułości, i w warunkach bez możliwości oznaczenia DD. Uwzględniamy zastosowanie oceny prawdopodobieństwa klinicznego w ukierunkowaniu procesu diagnostycznego, możliwość wykluczenia DVT przy ujemnym wyniku oznaczenia DD lub ultrasonograficznego testu uciskowego (compression ultrasound - CUS) oraz znaczenie kolejnych badań diagnostycznych po wykonaniu badań wstępnych (zastosowanie CUS w przypadku dodatniego wyniku oznaczenia DD, oznaczenie DD po uzyskaniu ujemnego wyniku CUS i powtórne wykonywanie CUS), w zależności od prawdopodobieństwa DVT na początku procesu diagnostycznego. Zalecamy następujące postępowanie: jeżeli oznaczenie DD testem o dużej lub umiarkowanej czułości nie jest możliwe, rozpoznanie DVT należy oprzeć na wyniku CUS; jeżeli oznaczenie DD jest możliwe, u pacjentów z małym lub pośrednim prawdopodobieństwem DVT (ocenionym za pomocą skali Wellsa) należy oznaczyć DD testem o dużej czułości, w celu określenia czy konieczne jest wykonanie CUS; pacjentów z małym wyjściowym prawdopodobieństwem DVT i ujemnym wynikiem oznaczenia DD za pomocą testu 0 dużej lub umiarkowanej czułości należy jedynie obserwować, bez wykonywania dalszych badań diagnostycznych; aby u pacjentów z dużym wyjściowym prawdopodobieństwem DVT wykonywać CUS bez oznaczania DD. 